\title{
Cost-benefit Analysis of Corn Production in China*
}

\author{
Chunli Wan \\ College of Economics and Management \\ Shenyang Agricultural University \\ Shenyang, China
}

\author{
Wen Shi** \\ College of Economics and Management \\ Shenyang Agricultural University \\ Shenyang, China \\ **Corresponding Author
}

\author{
Luyi Chen \\ College of Economics and Management \\ Shenyang Agricultural University \\ Shenyang, China
}

\begin{abstract}
This paper studies the changes of corn production cost and benefit in recent 20 years through specific data in China. And it analyses the effects of fertilizer costs, mechanical action cost, indirect cost, labor cost and government policy on the changes of production cost of maize in China. In view of the current situation of maize production cost in China, it puts forward suggestions for large-scale land production, increasing the use of agricultural machinery, replacing chemical fertilizer with farm manure and reasonable support from government policies.
\end{abstract}

Keywords-corn cost; cost-benefit analysis; influence factors

\section{INTRODUCTION}

Crop cost includes production cost and land cost. Production cost is an important part of total production cost of agricultural products. In recent years, the production cost of agricultural products in China has increased rapidly, which is one of the important factors affects farmers' income. Based on the data of "Compilation of national cost and income data for agricultural products", this paper studies the changes of production cost and income of Maize in China and analyses factors affecting production cost and income. Meanwhile, it puts forward some suggestions for reducing production cost and improving farmers' income reasonably.

\section{The Cost StRucture AND CHANGING Situation OF CORN PRODUCTION IN CHINA}

\section{A. Production Cost}

Production cost refers to the material data value and labor cost which are consumed during the production process for the production of the product, including material and service costs and labor costs. Material and service costs include direct production costs and indirect production costs, among which direct costs include seed costs, fertilizer costs and

*Sponsors: The research was sponsored by the Education Department Project of Liaoning Province ((Project No. WSNZD201701), the Teaching Research Project of Shenyang Agricultural University, ((Project No. 201829), the Education Science "thirteen five" project of Liaoning Province (Project No. JG17DB442) pesticide costs which can be directly included in the crop material costs. And indirect costs include fixed asset depreciation costs, taxes, insurance costs and other costs which can only be counted into the cost through apportionment. Labor cost is composed of household labor discount and labor cost. The overall change in the cost of nationwide corn production from 1997 to 2016 is increased after slightly decreased. The change trend of material and service costs and labor costs in production costs is similar to the change of production costs, which first decreases and then increases gradually. As shown in "Table I", the cost of labor has been reduced from 159 Yuan in 1997 to 126.8 Yuan in 2000, and it increased to 474.68 Yuan in 2014. Besides, its share of production costs decreased from $47.81 \%$ in 1997 to $43.49 \%$ in 2002, and increased to $56.54 \%$ in 2014 . Material and service costs decreased from 173.59 Yuan in 1997 to 157.36 Yuan in 2001, and increased to 376.22 Yuan in 2015. However, its share of production cost increased first and then decreased in the same period, from 52.19\% in 1997 to $56.51 \%$ in 2002 and then dropped to $43.46 \%$ in 2014 . It indicates that the production cost and the material and service costs included in the production cost, as well as labor costs experienced a process of falling first and then rising, but the extent and speed of labor costs are faster, and labor cost begin to become an important factor affects the production cost. 
TABLE I. The Structure and Variation of National Corn Production Cost

\begin{tabular}{|c|c|c|c|c|c|}
\hline \multirow{2}{*}{ Year } & \multicolumn{2}{|c|}{$\begin{array}{l}\text { Material and Service } \\
\text { Ccosts }\end{array}$} & \multicolumn{2}{|c|}{ Labor Cost } & \multirow{2}{*}{$\begin{array}{c}\text { Total } \\
\text { production } \\
\text { cost }\end{array}$} \\
\hline & $\begin{array}{c}\text { Amount } \\
\left(\text { Yuan/667 } \mathrm{m}^{2}\right)\end{array}$ & $\begin{array}{c}\text { Proportion } \\
\text { (\%) }\end{array}$ & $\begin{array}{c}\text { Amount } \\
(\text { Yuan/667 m })\end{array}$ & $\begin{array}{c}\text { Proportion } \\
\text { (\%) }\end{array}$ & \\
\hline 1997 & 173.59 & $52.19 \%$ & 159.00 & $47.81 \%$ & 332.59 \\
\hline 1998 & 170.72 & $55.46 \%$ & 137.10 & $44.54 \%$ & 307.82 \\
\hline 1999 & 163.02 & $56.00 \%$ & 128.11 & $44.00 \%$ & 291.13 \\
\hline 2000 & 158.50 & $55.56 \%$ & 126.80 & $44.44 \%$ & 285.30 \\
\hline 2001 & 157.36 & $54.50 \%$ & 131.40 & $45.50 \%$ & 288.76 \\
\hline 2002 & 171.42 & $56.51 \%$ & 131.94 & $43.49 \%$ & 303.36 \\
\hline 2003 & 167.43 & $56.25 \%$ & 130.22 & $43.75 \%$ & 297.65 \\
\hline 2004 & 173.77 & $55.29 \%$ & 140.49 & $44.71 \%$ & 314.26 \\
\hline 2005 & 176.08 & $54.27 \%$ & 148.38 & $45.73 \%$ & 324.46 \\
\hline 2006 & 188.38 & $55.68 \%$ & 149.94 & $44.32 \%$ & 338.32 \\
\hline 2007 & 198.74 & $55.43 \%$ & 159.78 & $44.57 \%$ & 358.52 \\
\hline 2008 & 243.31 & $57.89 \%$ & 176.98 & $42.11 \%$ & 420.29 \\
\hline 2009 & 241.05 & $55.59 \%$ & 192.61 & $44.41 \%$ & 433.66 \\
\hline 2010 & 260.54 & $52.57 \%$ & 235.10 & $47.43 \%$ & 495.64 \\
\hline 2011 & 308.45 & $51.07 \%$ & 295.49 & $48.93 \%$ & 603.94 \\
\hline 2012 & 344.58 & $46.38 \%$ & 398.40 & $53.62 \%$ & 742.98 \\
\hline 2013 & 359.71 & $44.13 \%$ & 455.37 & $55.87 \%$ & 815.08 \\
\hline 2014 & 364.80 & $43.46 \%$ & 474.68 & $56.54 \%$ & 839.48 \\
\hline 2015 & 376.22 & $44.53 \%$ & 468.72 & $55.47 \%$ & 844.94 \\
\hline 2016 & 369.55 & $44.65 \%$ & 458.10 & $55.35 \%$ & 827.65 \\
\hline
\end{tabular}

\section{B. Material and Service Costs}

As shown in "Table II", material and service costs are divided into direct and indirect costs. Direct costs include seed fees, fertilizer costs, other direct costs and 11 other contents. And indirect costs include fixed asset depreciation, insurance premium, financial expenses and other 5 contents. The following are several indicators from 1997 to 2016 which are selected to reflect the composition and variation trend of material and service costs. In the past 20 years, the material and service costs and direct costs of corn in China have been decreasing first and then increasing year by year. Structurally, the proportion of direct costs in material and service costs decreases first, then increases and finally becomes stable. The share of direct spending has been falling since 2008, but the extent of decrease is small. However, the proportion of indirect costs increases first and then decreases rapidly.

TABle II. The Structure And Change of National Corn Material and Service FeE

\begin{tabular}{|l|l|l|l|l|l|}
\hline \multirow{2}{*}{ Year } & \multicolumn{2}{|c|}{ Direct cost } & \multicolumn{2}{c|}{ Indirect costs } & $\begin{array}{c}\text { Material and } \\
\text { service costs }\end{array}$ \\
\cline { 2 - 6 } & $\begin{array}{c}\text { Amount } \\
\left.\text { Yuan/667 } \mathbf{m}^{2}\right)\end{array}$ & $\begin{array}{c}\text { Proportion } \\
\text { (\%) }\end{array}$ & $\begin{array}{c}\text { Amount } \\
\left.\text { Yuan/667 } \mathbf{m}^{2}\right)\end{array}$ & $\begin{array}{c}\text { Proportion } \\
\text { (\%) }\end{array}$ & $\begin{array}{c}\text { Amount } \\
\left(\text { Yuan/667 } \mathbf{m}^{2}\right)\end{array}$ \\
\hline 1997 & 148.45 & $85.52 \%$ & 25.14 & $14.48 \%$ & 173.59 \\
\hline 1998 & 144.17 & $84.45 \%$ & 26.55 & $15.55 \%$ & 170.72 \\
\hline 1999 & 138.34 & $84.86 \%$ & 24.68 & $15.14 \%$ & 163.02 \\
\hline 2000 & 131.74 & $83.12 \%$ & 26.76 & $16.88 \%$ & 158.50 \\
\hline 2001 & 131.51 & $83.57 \%$ & 25.85 & $16.43 \%$ & 157.36 \\
\hline 2002 & 138.77 & $80.95 \%$ & 32.65 & $19.45 \%$ & 171.42 \\
\hline 2003 & 136.35 & $81.44 \%$ & 31.08 & $18.56 \%$ & 167.43 \\
\hline 2004 & 154.82 & $89.09 \%$ & 18.95 & $10.91 \%$ & 173.77 \\
\hline 2005 & 168.98 & $98.97 \%$ & 7.10 & $4.03 \%$ & 176.08 \\
\hline 2006 & 183.41 & $97.36 \%$ & 4.97 & $2.64 \%$ & 188.38 \\
\hline 2007 & 193.78 & $97.50 \%$ & 4.96 & $2.50 \%$ & 198.74 \\
\hline 2008 & 237.99 & $97.81 \%$ & 5.32 & $2.19 \%$ & 243.31 \\
\hline 2009 & 235.68 & $97.77 \%$ & 5.37 & $2.23 \%$ & 241.05 \\
\hline 2010 & 254.27 & $97.59 \%$ & 6.27 & $2.41 \%$ & 260.54 \\
\hline 2011 & 300.98 & $97.58 \%$ & 7.47 & $2.42 \%$ & 308.45 \\
\hline 2012 & 336.21 & $97.57 \%$ & 8.37 & $2.43 \%$ & 344.58 \\
\hline 2013 & 350.05 & $97.31 \%$ & 9.66 & $2.69 \%$ & 359.71 \\
\hline 2014 & 355.24 & $97.38 \%$ & 9.56 & $2.62 \%$ & 364.80 \\
\hline 2015 & 364.96 & $97.01 \%$ & 11.26 & $2.99 \%$ & 376.22 \\
\hline 2016 & 358.32 & $96.96 \%$ & 11.23 & $3.04 \%$ & 369.55 \\
\hline
\end{tabular}

In direct costs, seed costs, fertilizer costs and machinery costs account for a large proportion, and the increase of direct costs is mainly caused by the increase of fertilizer costs and machinery operating costs ("Table III"). Fertilizer 
costs increased significantly in 2008 but decreased in the past two years. Since 2010, machinery operating costs have increased significantly, and its ratio is about to catch up with that of fertilizer. This shows that although fertilizer cost is an important factor affects direct cost, with the development of environmental protection and organic agriculture in recent years, fertilizer cost began to decrease, and agricultural modernization makes machinery operating cost gradually become a significant factor affecting direct cost. ("Fig. 1")

TABLE III. The Structure OF NATIONAL CORN DiRECT COST

\begin{tabular}{|l|l|l|l|}
\hline Years & Seed cost & $\begin{array}{c}\text { Chemical } \\
\text { fertilizers }\end{array}$ & $\begin{array}{c}\text { Mechanical } \\
\text { operation cost }\end{array}$ \\
\hline 1997 & $11.65 \%$ & $44.34 \%$ & $8.45 \%$ \\
\hline 1998 & $11.96 \%$ & $44.72 \%$ & $8.71 \%$ \\
\hline 1999 & $12.37 \%$ & $44.32 \%$ & $9.45 \%$ \\
\hline 2000 & $11.69 \%$ & $43.92 \%$ & $11.16 \%$ \\
\hline 2001 & $11.82 \%$ & $40.00 \%$ & $10.85 \%$ \\
\hline 2002 & $15.16 \%$ & $42.35 \%$ & $10.99 \%$ \\
\hline 2003 & $13.15 \%$ & $44.66 \%$ & $11.24 \%$ \\
\hline 2004 & $13.44 \%$ & $48.19 \%$ & $12.18 \%$ \\
\hline 2005 & $14.54 \%$ & $47.92 \%$ & $13.47 \%$ \\
\hline 2006 & $14.12 \%$ & $46.45 \%$ & $15.79 \%$ \\
\hline 2007 & $13.89 \%$ & $45.63 \%$ & $17.72 \%$ \\
\hline 2008 & $11.97 \%$ & $50.67 \%$ & $18.12 \%$ \\
\hline 2009 & $13.55 \%$ & $46.28 \%$ & $20.07 \%$ \\
\hline 2010 & $15.08 \%$ & $42.63 \%$ & $22.86 \%$ \\
\hline 2011 & $15.14 \%$ & $43.04 \%$ & $23.31 \%$ \\
\hline 2012 & $15.47 \%$ & $42.47 \%$ & $25.05 \%$ \\
\hline 2013 & $15.72 \%$ & $40.61 \%$ & $27.23 \%$ \\
\hline 2014 & $15.55 \%$ & $36.73 \%$ & $29.59 \%$ \\
\hline 2015 & $15.60 \%$ & $35.94 \%$ & $30.68 \%$ \\
\hline 2016 & $15.79 \%$ & $35.18 \%$ & $31.94 \%$ \\
\hline & & & \\
\hline
\end{tabular}

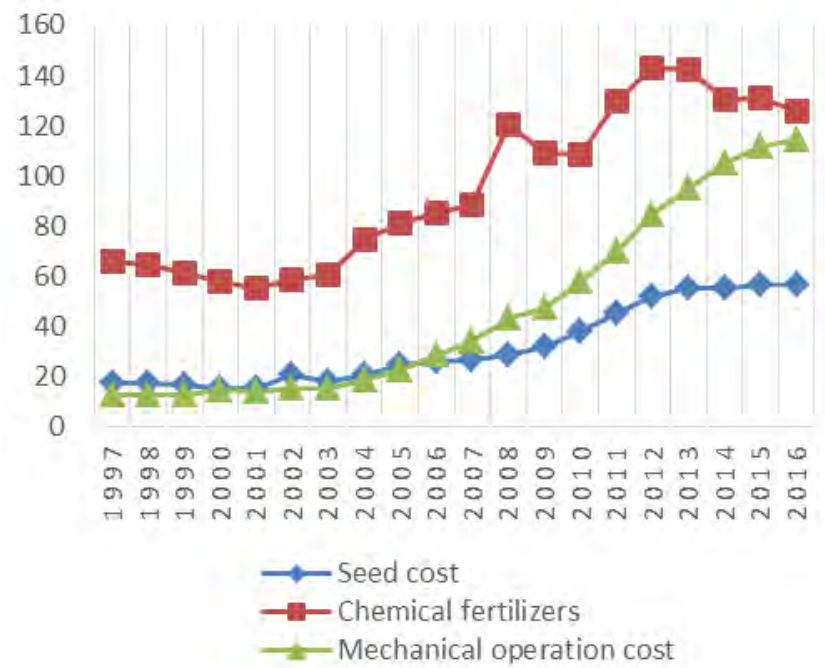

Fig. 1. The data of seed cost, chemical fertilizers and mechanical operation cost.

In "Table IV", the sharp decline in indirect costs is mainly due to the abolition of agricultural taxes. With the popularity of agricultural insurance, insurance premium has gradually become one of the important factors affecting indirect costs.

TABLE IV. The STRUCTURE AND VARIATION OF NATIONAL CORN INDIRECT COST

\begin{tabular}{|c|c|c|c|c|c|c|c|}
\hline \multirow{2}{*}{ Year } & \multicolumn{2}{|c|}{ Depreciation of fixed assets } & \multicolumn{2}{|c|}{ Tax } & \multicolumn{2}{|c|}{ Insurance } & \multirow{2}{*}{$\begin{array}{c}\begin{array}{c}\text { Total indirect } \\
\text { cost }\end{array} \\
\text { Amount } \\
\left(\text { Yuan } / 667 \mathrm{~m}^{2}\right)\end{array}$} \\
\hline & $\begin{array}{c}\text { Amount } \\
\left(\text { Yuan/667 m } \mathrm{m}^{2}\right)\end{array}$ & $\begin{array}{c}\text { Proportion } \\
\text { (\%) }\end{array}$ & $\begin{array}{c}\text { Amount } \\
\left(\text { Yuan } / 667 \mathrm{~m}^{2}\right)\end{array}$ & $\begin{array}{c}\text { Proportion } \\
\text { (\%) }\end{array}$ & $\begin{array}{c}\text { Amount } \\
\left(\text { Yuan } / 667 \mathrm{~m}^{2}\right)\end{array}$ & $\begin{array}{c}\text { Proportion } \\
\text { (\%) }\end{array}$ & \\
\hline 1997 & 5.50 & $21.88 \%$ & 11.35 & $45.15 \%$ & 0 & 0 & 25.14 \\
\hline 1998 & 6.47 & $24.37 \%$ & 11.21 & $42.22 \%$ & 0 & 0 & 26.55 \\
\hline 1999 & 6.37 & $25.81 \%$ & 10.72 & $43.44 \%$ & 0 & 0 & 24.68 \\
\hline 2000 & 6.39 & $23.88 \%$ & 11.94 & $44.62 \%$ & 0 & 0 & 26.76 \\
\hline 2001 & 5.42 & $20.97 \%$ & 12.38 & $47.89 \%$ & 0 & 0 & 25.85 \\
\hline 2002 & 5.49 & $16.81 \%$ & 23.04 & $70.57 \%$ & 0 & 0 & 32.65 \\
\hline 2003 & 5.43 & $17.47 \%$ & 21.44 & $68.98 \%$ & 0 & 0 & 31.08 \\
\hline 2004 & 4.37 & $23.06 \%$ & 11.26 & $59.42 \%$ & 0.08 & $0.42 \%$ & 18.95 \\
\hline 2005 & 3.79 & $53.38 \%$ & 0.89 & $12.54 \%$ & 0.04 & $0.56 \%$ & 7.10 \\
\hline 2006 & 3.04 & $61.17 \%$ & 0.89 & $17.91 \%$ & 0.06 & $1.21 \%$ & 4.97 \\
\hline 2007 & 2.76 & $55.65 \%$ & 0 & 0 & 0.16 & $3.23 \%$ & 4.96 \\
\hline 2008 & 3.17 & $59.59 \%$ & 0 & 0 & 0.15 & $2.82 \%$ & 5.32 \\
\hline 2009 & 2.79 & $51.96 \%$ & 0 & 0 & 0.90 & $16.76 \%$ & 5.37 \\
\hline 2010 & 2.67 & $39.73 \%$ & 0 & 0 & 1.74 & $27.75 \%$ & 6.27 \\
\hline 2011 & 2.75 & $36.81 \%$ & 0 & 0 & 3.06 & $40.96 \%$ & 7.47 \\
\hline 2012 & 2.80 & $33.45 \%$ & 0 & 0 & 3.75 & $44.80 \%$ & 8.37 \\
\hline 2013 & 2.89 & $29.92 \%$ & 0 & 0 & 4.79 & $49.59 \%$ & 9.66 \\
\hline 2014 & 2.80 & $29.29 \%$ & 0 & 0 & 5.20 & $54.39 \%$ & 9.56 \\
\hline 2015 & 3.72 & $33.04 \%$ & 0 & 0 & 6.00 & $53.29 \%$ & 11.26 \\
\hline 2016 & 3.04 & $27.07 \%$ & 0 & 0 & 6.71 & $59.75 \%$ & 11.23 \\
\hline
\end{tabular}

Therefore, the change of material and service costs is mainly caused by the change of direct costs, and the mechanical operation fee in direct costs is gradually becoming the primary factor influencing direct costs.

\section{Labor Costs}

Labor cost includes household labor discount and employment expenses. From 1997 to 2016, the total 
production cost of corn in China rose at the beginning then dropped later, from 159.00 Yuan in 1997 to 126.80 Yuan in 2000 and then increased to 474.68 Yuan in 2014. And household labor discount decreased from 159.00 Yuan in 1997 to 99.75 Yuan in 1999 and rose to 447.17 Yuan in 2015. The employment cost increased suddenly to 28.36 Yuan in 1999, fell to 6.80 Yuan in the second year, and then increased year by year. And it increased significantly in 2012 . It means that China's corn production mainly relies on family labor family management. Although employment costs continue to increase, it's relatively small. As can be seen from "Table V", the number of family working hours has continued to decline over the past 20 years, while the number of days of employment shows a trend of decline after rising. This shows that China's corn production productivity has been improved, and the agricultural mechanization has been developed. Although the number of employed workers has increased, it is mainly based on family production. Daily salary and employee wages have been continually growing for 20 years. It indicates that we need higher wages to meet workers' remuneration.

TABle V. The Structure and Change of National Corn labor Cost

\begin{tabular}{|c|c|c|c|c|c|c|c|}
\hline Year & $\begin{array}{c}\text { Household } \\
\text { labor discount } \\
\left(\text { Yuan } / 667 \mathrm{~m}^{2}\right)\end{array}$ & $\begin{array}{c}\text { Number of } \\
\text { family's } \\
\text { working days } \\
\text { (day) }\end{array}$ & $\begin{array}{c}\text { Labor day } \\
\text { wages } \\
(\text { Yuan/667 m²) }\end{array}$ & $\begin{array}{l}\text { Workers cost } \\
(\text { Yuan/667 m²) }\end{array}$ & $\begin{array}{c}\text { Employee } \\
\text { number } \\
(\text { Yuan/667 m²) }\end{array}$ & $\begin{array}{c}\text { Employee } \\
\text { number } \\
\text { (Yuan) }\end{array}$ & $\begin{array}{c}\text { Total labor } \\
\text { cost } \\
\left(\text { Yuan } / 667 \mathrm{~m}^{2}\right)\end{array}$ \\
\hline 1997 & 159.00 & 15.90 & 10 & 0 & 0 & 0 & 159.00 \\
\hline 1998 & 133.44 & 13.90 & 9.60 & 3.66 & 0.30 & 12.20 & 137.10 \\
\hline 1999 & 99.75 & 10.50 & 9.50 & 28.36 & 2.30 & 12.33 & 128.11 \\
\hline 2000 & 120.00 & 12.00 & 10.00 & 6.80 & 0.40 & 17.00 & 126.80 \\
\hline 2001 & 124.80 & 12.00 & 10.40 & 6.80 & 0.40 & 16.50 & 131.40 \\
\hline 2002 & 122.10 & 11.10 & 11.00 & 9.84 & 0.60 & 16.40 & 131.94 \\
\hline 2003 & 119.84 & 10.70 & 11.20 & 10.38 & 0.60 & 17.30 & 130.22 \\
\hline 2004 & 128.64 & 9.39 & 13.70 & 11.85 & 0.58 & 20.43 & 140.49 \\
\hline 2005 & 138.92 & 9.08 & 15.30 & 9.46 & 0.41 & 23.07 & 148.38 \\
\hline 2006 & 140.61 & 8.32 & 16.90 & 9.33 & 0.35 & 26.66 & 149.94 \\
\hline 2007 & 147.92 & 7.91 & 18.70 & 11.86 & 0.38 & 31.21 & 159.78 \\
\hline 2008 & 162.86 & 7.54 & 21.60 & 14.12 & 0.36 & 39.22 & 176.98 \\
\hline 2009 & 178.39 & 7.19 & 24.80 & 14.22 & 0.31 & 46.02 & 192.61 \\
\hline 2010 & 220.35 & 7.04 & 31.30 & 14.75 & 0.28 & 52.10 & 235.10 \\
\hline 2011 & 276.28 & 6.91 & 40.00 & 19.21 & 0.27 & 70.36 & 295.49 \\
\hline 2012 & 370.22 & 6.61 & 56.00 & 28.18 & 0.34 & 82.89 & 398.40 \\
\hline 2013 & 426.97 & 6.28 & 68.00 & 28.40 & 0.32 & 89.29 & 455.37 \\
\hline 2014 & 446.40 & 6.00 & 74.40 & 28.28 & 0.30 & 95.53 & 474.68 \\
\hline 2015 & 447.17 & 5.73 & 78.00 & 21.55 & 0.22 & 100.22 & 468.72 \\
\hline 2016 & 433.13 & 5.32 & 81.40 & 24.97 & 0.25 & 99.88 & 458.10 \\
\hline
\end{tabular}

\section{THE LAND COST STRUCTURE AND VARIATION OF CORN IN CHINA}

Land cost refers to the cost of land input as a factor of production into production, including land rent on circulation and lease on self-owned land. As shown in "Table VI", from 1997 to 2016, the land cost of corn in China was on the rise. From 1998 to 2001, it decreased slightly, but it increased year by year from 2002. And the trend of self-owned land rent discount is consistent with the land cost. But the rent of land circulation fluctuates greatly from 1998 to 2006, and tends to increase steadily from 2007. Besides, the rent of land circulation occupies a small proportion. This shows that farmers mainly grow corn on the land they own. Although the situation of non-contracted land producing corn has increased, the proportion is still small.
TABLE VI. The Structure AND Change of NAtional Corn LAND Cost

\begin{tabular}{|l|l|l|l|}
\hline Year & $\begin{array}{c}\text { Mobile land } \\
\left(\text { Yuan/667 } \mathbf{~}^{\mathbf{2}}\right)\end{array}$ & $\begin{array}{c}\text { Proprietary land } \\
\left(\text { Yuan/667 } \mathbf{~}^{\mathbf{2}} \text { ) }\right.\end{array}$ & $\begin{array}{c}\text { Land cost } \\
\left(\text { Yuan/667 } \mathbf{~}^{\mathbf{2}} \text { ) }\right.\end{array}$ \\
\hline 1997 & 0 & 25.84 & 25.84 \\
\hline 1998 & 6.89 & 41.85 & 48.74 \\
\hline 1999 & 4.86 & 41.22 & 46.08 \\
\hline 2000 & 5.01 & 40.25 & 45.26 \\
\hline 2001 & 4.03 & 35.09 & 39.12 \\
\hline 2002 & 3.59 & 44.61 & 48.20 \\
\hline 2003 & 3.74 & 46.26 & 49.98 \\
\hline 2004 & 6.77 & 54.67 & 61.44 \\
\hline 2005 & 5.58 & 62.24 & 67.82 \\
\hline 2006 & 5.57 & 67.88 & 73.45 \\
\hline 2007 & 6.47 & 84.71 & 91.18 \\
\hline 2008 & 8.48 & 94.68 & 103.16 \\
\hline 2009 & 9.09 & 108.35 & 117.44 \\
\hline 2010 & 12.57 & 124.38 & 136.95 \\
\hline 2011 & 13.62 & 146.67 & 160.29 \\
\hline 2012 & 18.35 & 162.89 & 181.24 \\
\hline 2013 & 20.76 & 176.20 & 196.96 \\
\hline 2014 & 24.04 & 200.37 & 224.41 \\
\hline 2015 & 28.82 & 209.96 & 238.78 \\
\hline 2016 & 30.16 & 207.78 & 237.94 \\
\hline & & & \\
\hline
\end{tabular}




\section{Changes of Net Profit And Cost-Profit Ratio OF CORN IN CHINA}

As shown in "Fig. 2", from 1997 to 2016, the net profit and the cost yield of corn in China fluctuated greatly. In 2011 and 2010, both reached the highest, with the amount of 263.09 Yuan and 37.89 percent respectively. In 2016, both of them reached the lowest, with the amount of -299.70 Yuan and 28.13 percent respectively. In addition, the net profit and cost margin of corn have declined sharply in the past two years, which indicates that China's corn market is not optimistic in the past two years. This is also closely related to the high cost of the previous analysis.

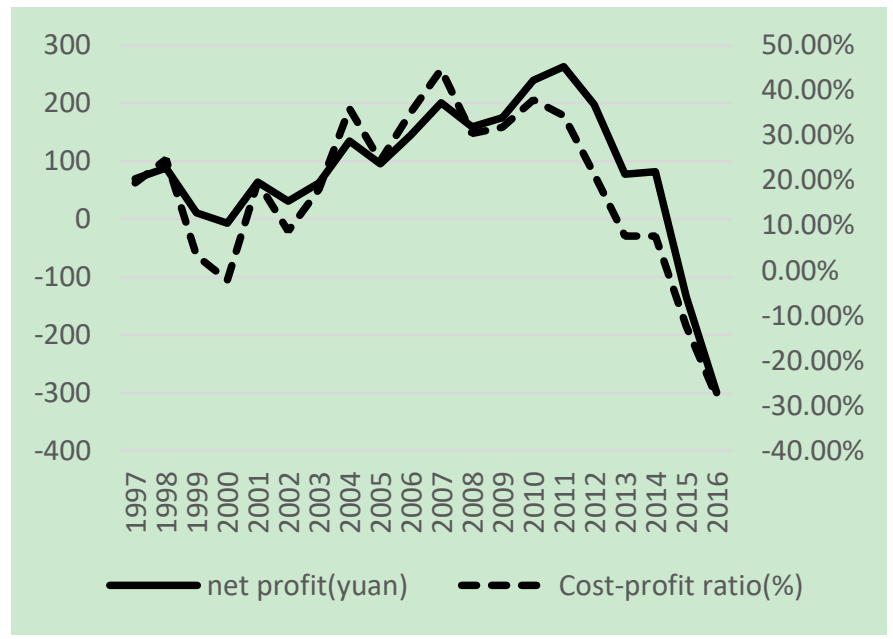

Fig. 2. The data of net profit and profit margin of corn in China.

\section{FACTORS INFLUENCING THE CHANGE OF CORN PRoduction Cost IN CHINA}

From 1997 to 2016, the main factors influencing the change of corn production cost in China gradually changed from material and service cost to labor cost. Among the Material and service costs, fertilizer costs and Mechanical action costs in direct costs have become important factors affecting the changes in corn production costs. But with the strengthening of environmental protection and the promotion of organic agriculture in our country in recent years, the proportion of fertilizer costs has a tendency to decrease gradually. And with the development of agricultural mechanization, mechanical action cost is becoming more and more significant impact in production costs. Besides, in recent years, the proportion of premium in indirect costs has been increasing every year, which has also become one of the important factors affecting production cost. The influence of labor cost in production cost is mainly caused by the increase of daily salary and employee wages year by year, which indicates that labor remuneration, is also an important factor affecting production cost.

\section{CONCLUSION AND SUGGESTIONS}

In recent years, the production cost of corn in China has been increasing, among which the increase of labor cost is the most obvious part. And the mechanical action cost has also started to increase significantly, but the proportion is still little. The Labor hours have been decreasing year by year, and the fertilizer cost has been decreasing from nearly two years. Besides, the proportion of insurance premium has increased, and the net profit and cost margin of corn have fluctuated greatly. China's corn is mainly based on household production. Farmers' land is scattered, and household labor discount are high, resulting in a continuous and rapid increase in labor costs. And then it raises production costs. Under this circumstance, the following suggestions are proposed:

- The land contracting system should be further improved to achieve large-scale production of concentrated land. By increasing the use of agricultural machinery, the labor force is gradually liberated. Labor efficiency is increased, and then labor costs are reduced.

- We should strongly promote organic agriculture and enhance farmers' awareness of environmental protection and sustainable development. And we should recommend farmers apply chemical fertilizers scientifically and rationally and reduce the use of chemical fertilizers and pesticides.

- The government should continue to introduce relevant policies to help farmers reduce production costs and thus increase their income.

\section{REFERENCES}

[1] China rural statistical yearbook, 2017.

[2] Xue Li,Yixiang Zong. Cost-benefit analysis of corn production in hebei province, Hebei Agricultural University, 2016.

[3] Nana Mu, Study on transformation and upgrading of corn value chain under the background of supply-side structural reform,College of agriculture and rural development, Renmin University of China, 2016.

[4] Junhong Pei,Yinping Li, Analysis of wheat production cost and benefit in hebei province. Economic management department of Shijiazhuang Railway Vocational and Technical College, 2015.

[5] Compilation of national agricultural products cost and income data, 2017. 